\title{
Hydrologic Interdependencies and Human Cooperation: The Process of Adapting to Droughts
}

\author{
JOANNA ENDTER-WADA \\ Department of Environment and Society, Utah State University, Logan, Utah \\ THERESA SELFA \\ Department of Sociology, Anthropology, and Social Work, Kansas State University, Manhattan, Kansas \\ LISA W. WELSH \\ Department of Environment and Society, Utah State University, Logan, Utah
}

(Manuscript received 22 January 2009, in final form 16 June 2009)

\begin{abstract}
The Bear River Basin, which includes portions of Idaho, Utah, and Wyoming in the United States, has a dynamic history of human hydrologic adaptations in relation to a highly variable water supply. These adaptations are embedded in a geographical setting highly influenced by the legal, policy, and institutional contexts that govern allocation of water in this generally arid region. In response to several years of drought and a historically low water year in 2004, water users in the Bear River Basin tested the efficacy of the "law of the river" and innovative agreements that they had negotiated in recent years to help mitigate impacts related to water shortages. Three innovations were identified as being key to a successful response to the 2004 drought: 1) a precedent-setting voluntary settlement agreement, 2) technical work in river modeling and instrumentation, and 3) extraordinary communication strategies employed throughout the drought. Based on case study research and utilizing a "ways of knowing" theoretical framework, the authors report on an unfolding contemporary history of how people in the Bear River Basin have learned to deal with uncertainties and risks associated with both droughts and floods. Their story has important implications for the understanding of conflict and cooperation in water systems, management of transboundary waters, and the promotion of sustainable water resource governance.
\end{abstract}

\section{Introduction}

Increased attention is being paid to preparing for and responding to droughts because of the widespread occurrence of droughts in recent years, the potential threat of an increase in water-related disasters due to climate change, and a documented increase in social and economic vulnerability to droughts. The need to monitor and characterize climatic features of droughts (severity, intensity, duration, spatial coverage) and assess drought consequences has resulted in efforts to better define and understand drought phenomena. In a current paradigm shift for understanding drought, scholars and water managers

Corresponding author address: Joanna Endter-Wada, Department of Environment and Society, Old Main Hill 5215, Utah State University, Logan, UT 84322-5215.

E-mail: Joanna.Endter-Wada@usu.edu are arguing for more proactive, risk-based management approaches to replace the reactive, crisis-management approaches generally characterizing drought responses (Smakhtin and Schipper 2008; Wilhite 2005; Wilhite et al. 2007). There is growing recognition that droughts and other climate change-related events occur in social as well as natural contexts, which shape people's vulnerability and adaptive capacity (Adger 2006; Berkes and Folke 1998; Hulme 2007; Ingram and Endter-Wada 2009; O'Brien et al. 2007; Simelton et al. 2009; Smit and Wandel 2006).

Drought vulnerability is part of a larger global concern over increasing scarcity of freshwater supplies to meet growing demands (Barlow 2008; de Villiers 2000; Gleick et al. 2002; Postel and Richter 2003). Water scarcity is a prominent example of risks posed by various types of environmental stress (Fraser 2007; Rolfe 2008; Watts and Bohle 1993). Human capacity to adapt to environmental 
stress has long been of scholarly interest but is receiving increased attention as part of science and policy focused on issues of global climate change and sustainability (Bernhardt et al. 2006; Burton et al. 2002; Clark and Dickson 2003; Janssen et al. 2006; Ostrom 2008). Predictions from climate change research suggest the need to better understand the types of adaptations required to deal with higher climatic and hydrologic variability (Epstein and McCarthy 2004; Fischhendler 2004). Successful human adaptations require, in part, understanding societal complexity, managing contexts instead of outputs, and fostering institutions of problem solving that are themselves sustainable (Allen et al. 2003; Tainter 1988).

How people adapt to water scarcity and whether this leads to conflict or cooperation is the subject of much debate. Because potential conflicts over water are often tied to national security concerns and growing demands in the international arena for more equitable allocation of the earth's natural resources, the ways in which water conflicts are managed and cooperation is fostered have important political, economic, and social implications (Draper 2006; Grover 2007; Just and Netanyahu 1998; Shiva 2002; Wolf 2002). Leading water policy scholars argue that addressing water challenges requires policy innovations that promote equity and sustainable water resource governance (Blatter and Ingram 2001; Whiteley et al. 2008).

This paper presents a case study focused on how people in the Bear River Basin of Idaho, Utah, and Wyoming responded to the 2004 drought, one of the worst drought years for this region in a century. During spring 2004, people involved in Bear River water management anticipated and feared that drought would strain institutional structures for water management and lead to conflicts over scarce water supplies. However, when the season resulted in an extraordinary level of cooperation and only one lawsuit, participants were relieved but mostly surprised that they made it through such a severe drought with minimal conflict, despite the hardships drought imposed. This paper provides a historically contextualized analysis of how hydrologic interdependencies and human cooperation contributed to the capacity to adapt to a highly variable water supply.

\section{Framework for understanding adaptation to drought}

Several threads in the existing water literature are important for framing our approach to understanding adaptation to drought in the Bear River Basin. The literature specifically focused on drought takes primarily a managerial approach and emphasizes how to define, predict, and prepare for droughts and assess their impacts (Wilhite 2005). Drought is generally framed as hazard or disaster, and responding to drought is understood in the context of impact/vulnerability assessment, risk analysis, and development of drought management plans (Durley and de Loe 2005; Polsky and Cash 2005; Wilhite and Buchanan-Smith 2005; Wilhite et al. 2005). Heavy emphasis on generalizability is aimed at developing models and measures for standardized drought prediction, monitoring, and mitigation (Hayes et al. 2005; Nicholls et al. 2005; Steinemann and Cavalcanti 2006). Human dimensions of drought are recognized in different definitions and characterizations of drought (e.g., meteorological, agricultural, hydrological, socioeconomic), emphasizing that drought severity is not solely due to climatic trends; in fact, human factors are important components of drought vulnerabilities and adaptive responses (Polsky and Cash 2005; Simelton et al. 2009; Wilhite and Buchanan-Smith 2005). Overall, however, the emphasis in drought management literature is on promoting more climatic and hydrologic science to better predict future droughts.

Much of the literature that analyzes transboundary situations characterized by scarce water resources seeks to understand conflict and cooperation in water systems and to identify what human behavior is characteristic in water scarce circumstances (Grover 2007; Just and Natanyahu 1998; Wolf 2002). Recent research tries to combat the general assumption that water scarcity inherently leads to conflict, as implied by wide use of the phrase "water wars." It documents that outright violence over water is the exception, that cooperation is far more common, especially in the international arena, and that the intensity of conflicts tends to increase when they are more localized (Wolf 1998; Wolf et al. 2003). Work focused on watershed collaboration and governance rooted in the theory and practice of conflict resolution analyzes procedural factors that contribute to finding common ground in more local, watershed-based attempts to manage limited water supplies (Beach et al. 2000; Clark et al. 1991). However, time and logistical constraints in "getting everyone to the table" and the dynamics of managing large groups in facilitated processes can sometimes frustrate structured collaboration efforts. We will argue for a more nuanced understanding of the interplay of conflict and cooperation in water systems.

Case studies in Reflections on Water (Blatter and Ingram 2001) and Water, Place, and Equity (Whiteley et al. 2008) illustrate the importance of understanding water in terms of the meanings it has in local contexts and shifting focus from "units, entities, or actors toward the flows, interactions, linkages, and bonds among these 
units" (Blatter et al. 2001, p. 7). These emphases are supported by methodological reliance on network analysis, discourse analysis, and historical and ethnographic analysis as well as the ways of knowing these approaches support. The editors reinforce the need to unbind water from traditional thinking dominated by law, engineering, and economics and understood through ontologies that view the world as a singular objective reality (elements of the managerial approach to drought). Attention to the "moral economy of water" recognizes that water is a "complex social good" that requires an "equally complex take on sustainability" centered on sustaining meanings that water has for people (Arnold 2008). The conceptual approach and related analyses in these books reveal that water and its governance need to remain embedded in natural and cultural contexts where precedent and place are understood, where equity and justice concerns can be reconciled with efficiency issues, and where more inclusive management practices can foster deliberative democracy and promote adaptive learning over time. Attention to multiple meanings of water can help people seek more principled foundations for the process, content, and outcomes of policy (Feldman 1991; Schneider and Ingram 1997, 2005; Schneider and Ingram 2005; Whiteley et al. 2008).

We rely most heavily on the "ways of knowing" framework, which is theoretically grounded and methodologically focused on explaining cooperation as opposed to most management and policy analysis frameworks that are far better at explaining conflict (Feldman et al. 2006; Feldman and Khademian 2007; Lejano and Ingram 2008; Schneider and Ingram 2007; Weber and Khademian 2008). A way of knowing describes how one understands and makes sense of the relationships between elements (human and/or nonhuman) in a policy space (Schneider and Ingram 2007, p. 2). This framework for interpreting relationships between elements in a given policy domain is receptive to changes in the relationships between elements, so that ways of knowing are fluid and dynamic rather than static processes. This framework has several strengths in comparison with other policy theory frameworks in that it specifically recognizes that humans are guided by multiple motivations; sees knowing as a social process formed and molded by human interactions in specific contexts; explains how ways of knowing develop, diffuse, change, and gain prominence; seeks to understand the leverage points for bridging different ways of knowing; and focuses on how mobility and inclusiveness of networks and shared elements of different ways of knowing can become vehicles for cooperation (Schneider and Ingram 2007).

The ways of knowing framework draws on actornetwork theory and the sociology of associations, recognizing that "ways of structuring and knowing associated with a policy issue, even those that endure, are active and ongoing" and require "translation" more than "diffusion" (Feldman et al. 2006). Various ways of knowing can include political, scientific or technical, and local or experience-based perspectives. People can deliberate public policy issues by engaging in communities of participation through "informational work" (identifying and disseminating information, translating ideas, promoting synthesis) and "relational work" (creating connections between people and empathy for participants who represent different ways of understanding) (Feldman and Khademian 2007). They can also use tools such as boundary organizations, objects, and experiences that aid development of collective ways of knowing by informing deliberation and decision-making and nurturing problem-solving capacities (Guston 2001; Ingram and Endter-Wada 2009; Star and Griesemer 1989; Schneider and Ingram 2007).

Our framework for understanding hydrologic interdependencies and human cooperation in the Bear River Basin is briefly summarized here. We argue that drought adaptations in the Bear River Basin must be understood as relational along two dimensions: they are not just human-hydrologic adaptations but simultaneously the adaptations of people responding to each other within that hydrological context. Understanding these adaptations requires an approach that is fluid enough to understand the dynamic interplay of conflict and cooperation in the use of highly variable and generally scarce water supplies, grounded in the geographic and historical context, and focused on understanding people's ways of knowing water and ways of knowing each other. How the context evolves and where compromises rest at any point in time depend upon people's relative relationship to water resources vis-à-vis its current availability and other people's claims upon it. The context is shaped by past negotiations, settlements, and compromises as well as by future possibilities and threats defined by movement and exercise of agency within the policy sphere. In this context, people's information needs include not only scientific information from fields such as climatology and hydrology but also political information emerging from their interactions with each other that enables them to assess the incentives and stakes involved in pursuing conflict or cooperation. In short, they need to know as much about each other as they need to know about water resources. Our analysis implies that approaches to drought management should be less focused on predicting water supplies and developing drought plans and more focused on fostering governance processes for communication, interaction, and problem-solving in order to promote needed flexibility and adaptability to 
respond to specific ways water scarce situations unfold in changing spatial and temporal contexts.

\section{Research approach}

Impetus for this case study came from presentations and discussions at the Bear Lake Eco-Symposium held on 23-24 September 2004 in Garden City, Utah. This symposium was held near the end of the water year that encompassed the 2004 depth of a drought period that lasted from 1998 to 2007. While drought consequences were significant in terms of irrigation water shortages, lowering of the elevation of Bear Lake, and impacts to hydropower generation and recreation, symposium participants evaluated their efforts to deal with drought as amazingly successful, innovative, and worthy of documentation. Jack Barnett, Engineer Manager for the Bear River Commission, noted that they had "physically stretched" limited water supplies. Interestingly, panelists noted how many of them had been in conflicts over the years, yet they managed to cooperate through the worst drought any of them had ever known. Since they were experienced water veterans of the Bear River Basin, some nearing retirement, Jack Barnett expressed concern about who would take over management of the river and use what they had learned.

Accepting the challenge to investigate this story, the overall objective of our research was to document how water users in the Bear River Basin responded to the 2004 drought. We developed research protocols and interview questions to learn key elements of their story, including participants' assessments of success, what participants considered to be innovative, mechanisms for managing conflicts and furthering cooperation, physical constraints water managers faced in water distribution and how those were addressed, how people managed to physically stretch water supplies, how human factors shaped the Bear River water situation, difficult issues and how they were or were not resolved, elements of current water arrangements people thought might prove to be unstable over time, and what people interested in drought management could learn from the Bear River Basin.

Our research approach consisted of gathering and analyzing primary data from in-depth, semistructured interviews and participant observation and secondary data from historical and archival research. Interviews conducted with Bear River water officials and users were designed to obtain people's perspectives and insights concerning changes in water use practices in response to the 2004 drought. Interviewees represented agriculture, conservancy districts, municipalities, landowners, industry, recreation, and the environment. Interviews were recorded and transcribed and the content was analyzed for themes and reconstruction of drought events. Attendance at numerous water meetings included observational research and informal conversations. Legal, administrative, management, and other historical documents provided secondary data for understanding the evolving policy context. This multimethod approach was appropriate for developing a contextualized case study understanding of drought response.

\section{Bear River Basin}

In this section we present our case study findings. First, we describe the Bear River Basin's cooperative response to the 2004 drought. Then, we discuss development of human-hydrologic interdependencies in the Bear River Basin and illustrate how ways of knowing these interdependencies acted as a fulcrum for conflicts encountered and cooperation forged as people confronted challenges in manipulating the river for human use. This historical analysis illustrates how connections between physical and social dimensions of particular contexts affect vulnerability and adaptation to drought and helps to explain the 2004 drought response.

\section{a. Response to the 2004 drought}

In 2004, the Bear River Basin experienced a severe drought of a magnitude not seen since the 1930s. Because of Bear Lake, a large natural lake located in the middle of the watershed that is used as a storage facility (Fig. 1), irrigators had never run out of storage water since the 1930s drought. In 2004, Bear Lake storage water did run out when the lake dropped below 5904 feet in elevation (Fig. 2). Shareholders of Bear River Canal Company took out crop insurance for the first time and $60 \%$ of Utah small irrigators used up their water allocations within the first two weeks. For the first time since the 1958 Bear River Compact was passed, Bear River Canal Company made an in-state call on the river to force the Utah Division of Water Rights to order 90 upstream farmers to stop diverting water (Denton 2007). Despite these difficult circumstances, research participants were surprised they made it through the worst drought since 1936 with only one lawsuit. In the following subsections, we discuss the three innovations commonly identified in interviews as being key to cooperative success, as well as one instance that sheds light on the risks of not cooperating.

\section{1) BEAR LAKE SETTLEMENT AGREEMENTS}

In response to conflicts over depletion of storage water and the lowering of Bear Lake elevation during the early 1990s drought, a precedent-setting voluntary settlement agreement of 1995 was reached between irrigators, 


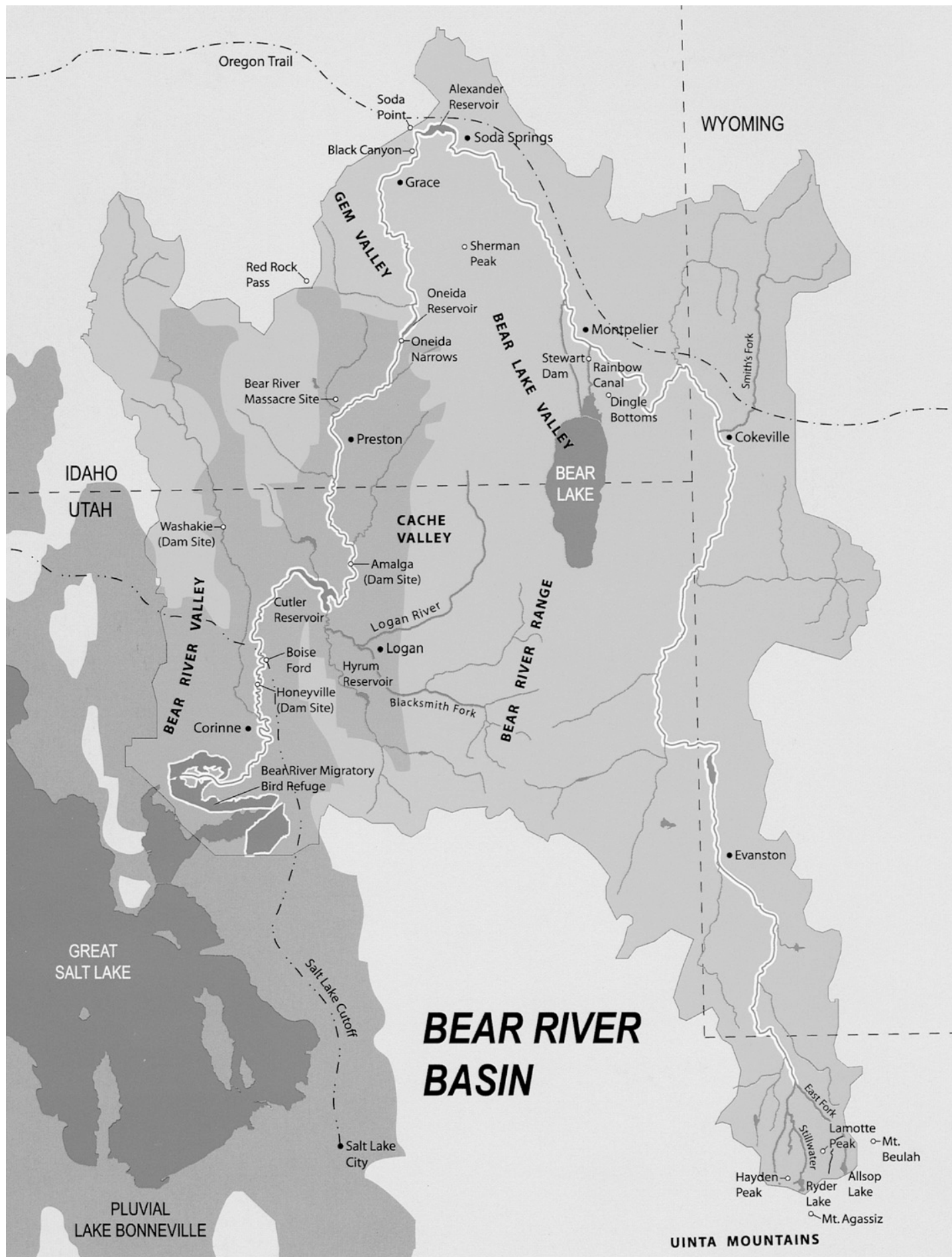

FIG. 1. The Bear River Basin. [Source: Denton (2007), inside front cover, map by Tim Lee. Courtesy of Utah State University Press.]

PacifiCorp, and Bear Lake Watch, Inc., a Bear Lake interest group composed of lake homeowners and businesses. This agreement was amended and restated in July of 2004. These settlements set precedents in several re- spects: 1) none of the three state water rights agencies nor the Bear River Commission is signatory to these agreements, yet they are fully recognized and operate as part of the "law of the river;" 2) the settlements overlay 


\section{Historic Bear Lake Hydrograph}

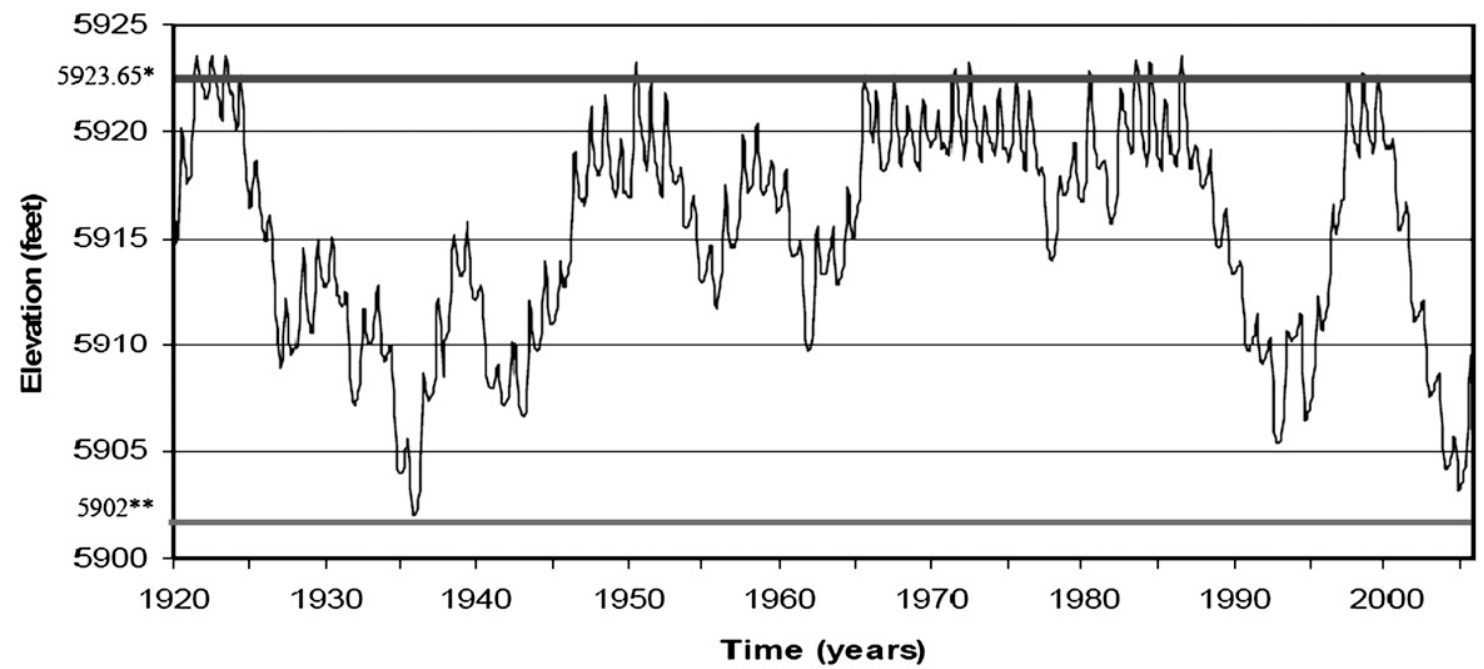

Source: Utah Division of Water Resources, 2005.

*Normal (or full)

$* *$ Historic Low (occurred in fall 1935)

FIG. 2. Historic Bear Lake hydrograph, 1920-2006. (Source: Utah Division of Water Resources.)

a key principle of riparian water law on a prior appropriation system, namely sharing shortages in times of scarcity among most irrigators in the system; and 3) the settlements did not negate or override existing statecertificated and court-decreed prior appropriation rights, which serve as the ultimate fallback position if the voluntary agreements unravel. However, the settlements were so well crafted by people embedded in and knowledgeable about the local context that Jody Williams, attorney for PacifiCorp, believes "even when they [users] do fight, when push comes to shove, I don't think they'll withdraw from the settlement agreements because they are personally invested."

Tremendous informational and relational work went into forming the settlement agreements that provide the framework for integrating lake and river interests. One outcome has been greater networking between water organizations throughout the Bear River Basin, with Bear Lake Watch exercising important relational leadership. In referring to the greater collaboration that has emerged but the unstructured way in which it is exercised, Claudia Cottle of Bear Lake Watch noted, "we don't need a seat at the table; we need a chair in each other's meetings." She and her husband David Cottle have also observed that the most important work occurs over lunches and dinners held in connection with various conferences, symposia, and meetings. Bear Lake Watch has taken the lead and hosted some of those informational and relational gatherings.

\section{2) RIVER MODELING AND INSTRUMENTATION}

In the period between the drought of the early 1990s and 2004, much technical work was done in modeling and instrumentation of the Bear River. Predictive models were developed to better anticipate water supply. Groundwater modeling for Cache Valley, Utah, helped resolve disputes between Idaho and Utah over the connections between groundwater and surface water flows. In the event of drought severe enough to precipitate an interstate call on the river, Idaho would have refused to deliver water across the state line into Utah to satisfy the senior prior appropriation rights at the end of the system unless it was assured that their inability to receive allocations was not due to withdrawals of groundwater in Utah (the modeling showed a negligible effect of groundwater withdrawals on surface water flows). Finally, streamflow accounting models developed independently by water officials in Idaho and Utah were calibrated and coordinated to the mutual satisfaction of water managers and users. While there had been talks of developing a single model, separate state models actually provide comfort to users because "we're checking on each other," Will Atkin of the Utah Division of Water Rights explained. 
In particular, the streamflow accounting models proved critical. These models were linked to river instrumentation that enabled real-time monitoring of diversions. By continuously tracking natural flow, storage water, and system losses throughout the lower division of the Bear River, these models provided information that alleviated suspicion and conflict among most water users. Everyone knew who was using water and when they were using it, so each person could understand their own needs and uses in relation to other people. These models were not aimed at reducing hydrologic uncertainty as much as at reducing human uncertainty by providing transparency. They instituted accountability and promoted better delivery coordination and efficiency, which was the key to physically stretching water supplies limited by drought. Schneider and Ingram (2007, p. 9) have observed that "Additions to existing ways of knowing or the development of a new way of knowing can be galvanized through new technology that promotes changes in perspectives."

\section{3) Communication STRATEgies}

Third, extraordinary communication strategies employed throughout the 2004 drought contributed to the successful response. PacifiCorp hosted open conference calls twice a week throughout the irrigation season in which discussions were held and decisions made about how to deliver scarce water supplies. These conference calls were enhanced by the river accounting models and real-time Internet-available water delivery data that people could access for decision making. Charles Holmgren, president of Bear River Canal Company, said, "I think those conference calls did a lot to improve the management of the limited supply of water... if you're not communicating with each other, you're conjuring up ideas in your mind someone is stealing water or not having it accounted correctly." These communication strategies enabled people to make decisions concerning their own use of water with greater and more transparent information not only about the resource but about what other people were doing. Dan Davidson, manager of Bear River Canal Company, explained that "the best plan in the world will not save any water if everybody isn't in agreement and ready to work together." Communication throughout the irrigation season resulted in coordination and trading of water deliveries, which provided flexibility that enabled them to "physically stretch water."

Interviewees indicated this communication and cooperation occurred because of the previous ten years of work to resolve problems that arose in response to drought in the early 1990s. Jody Williams said, "There wouldn't have been cooperation if we hadn't been laying the foundation for the previous ten years by working with everybody. The Bear Lake interests, the irrigators,
PacifiCorp, US Fish and Wildlife. Everybody started working together to solve some problems from the last drought." Some people would add that this work built upon the larger "law of the river" framework constructed over time in response to earlier droughts. Most significantly, the previous drought as severe as the one in 2004 occurred in 1936. In response to that drought, discussions were initiated that eventually led to the formation and passage of the 1958 Bear River Compact, which established the Bear River Commission. Jack Barnett believes, "If we had not had a procedure [formed in response to previous droughts], they might not have agreed [to cooperate in 2004] because one of the members might have said, 'oh, we can have an advantage here'." Interviewees generally recognized that the possibility of conflict still existed, but their work was aimed at furthering cooperation within the basin.

\section{4) RISKS OF NOT COOPERATING}

The one lawsuit from the 2004 drought was filed by a small irrigator who diverted water directly from the river. The Utah small irrigators were not organized into an irrigation company and therefore were not able to cooperate very effectively with each other or with other Bear River users. The small irrigators' lack of organization made it difficult for information to be gathered and disseminated. Only $30 \%$ of them showed up to a meeting held three weeks before they were shut off by the in-state call on the river. During the meeting, those who were present realized that it would be ideal for everyone to stop pumping for ten days so they could stretch their water supply and buy time to figure out how to deal with the drought. But realizing that only $30 \%$ of them were present at the meeting, they left resigned that it would be a "free-for-all" and decided to continue pumping since they did not have the time necessary to coordinate with the other $70 \%$. Eventually, it was determined that the small irrigators had used all of their allocated storage water, and they were shut off before many of them could completely harvest their crops. One small irrigator continued to irrigate and entered into a lawsuit with the State of Utah, disputing the nature of his water rights (the lawsuit was settled out of court when the irrigator agreed to stop pumping and the State of Utah agreed that the irrigator retained the right to dispute the nature of his water rights in the future). This example illustrates that because lack of organization hindered cooperation, the risk small pumpers incurred was running out of water too soon. After seeing the more successful outcome of entities who worked together, the small irrigators began organizing after the 2004 drought so that joint decisions could be made more effectively in future droughts. 


\section{b. Historical context of human-hydrologic interdependencies}

As Wallace Jibson, one of the most involved participant observers of Bear River Basin's water history noted, the Bear River is "a stream of geographic and political complexity" (Jibson 1991, p. 1).

\section{1) Challenges of GeOgRaphy AND HYDROLOGY}

The Bear River Basin is characterized by a highly variable, snow-driven, drought-prone montane ecosystem in the arid Rocky Mountain region of the western United States. Climatic and hydrologic variability pose the dual risks of droughts and floods. This hydroecologic reality makes storing water during winter and high spring runoff periods and controlling its release during summer essential for the region's economic activities and lifestyles.

Bear Lake, which straddles the Idaho-Utah state line (Fig. 1), is a large natural lake located in the middle of the watershed. The natural hydrology of Bear Lake has been altered by connecting the lake to Bear River so that the top 21.65 feet serves as a storage reservoir for water used downstream for irrigation and power generation. The Bear River is diverted at Stewart Dam via the Rainbow Canal into Mud Lake, a wetland connected to the northern end of Bear Lake (Fig. 3). A structure controls the flow of water from Mud Lake to Bear Lake. Depending on the lake's elevation, water for downstream use is either released by gravity flow or pumped back into the Bear River at the Lifton Pumping Station west of Montpelier, Idaho (Jibson 1991). Bear Lake also has important ecological, scenic, and recreational qualities. It is a popular summer resort for the surrounding region, and development of lakeside permanent and seasonal residences and commercial businesses has increased in recent years (Dean et al. 2007; Denton 2007).

Bear River is approximately 500 miles long and is "the largest stream in North America whose waters do not reach an ocean" (Jibson 1991, p. 1). Bear River starts in the High Uinta Mountains of Utah and follows a circuitous route that crosses state boundaries five times before terminating in the wetlands at the northern end of the Great Salt Lake. The length of the river and water contributed by various tributaries along its route create water delivery and management difficulties. The main difficulties are knowing whether water in the river is natural flow or storage releases, how much water is "lost" in transit through the river system (evaporation, seepage, spillage), how surface flows in the river are connected to groundwater, and who has rights to use water. Water controversies are complicated by the transboundary nature of the river and are exacerbated during times of scarcity.

A unique feature of the Bear River Basin is that the majority of water rights and water delivery infrastructure below Bear Lake came to be held by a private utility company, Utah Power and Light (UP\&L; it was Telluride Power until 1912 and is now PacifiCorp). This arrangement resulted from a series of developments and exchanges that enabled UP\&L to implement its "entire river concept" through establishing a large, controlled reservoir at Bear Lake and hydropower plants at selected locations below Bear Lake along Bear River (McCarthy 1987) (Fig. 4). In one exchange, UP\&L entered into a perpetual agreement with the Utah-Idaho Sugar Company (now Bear River Canal Company) to deliver a continuous flow of $900 \mathrm{cfs}$ between 1 May and 31 October and $150 \mathrm{cfs}$ between 1 November and 30 April, maintain all water diversion and power production infrastructure, and supplement natural flow water with Bear Lake storage water when necessary (McCarthy 1987; Jibson 1991). The Dietrich Decree in Idaho (Utah Power \& Light Company v. Last Chance Canal Company, Limited et al. in Equity No. 203, 14 July 1920) and the Kimball Decree in Utah (Utah Power \& Light v. Richmond Irrigation Company, et al., 21 February 1922) affirmed rights acquired by UP\&L to divert $5500 \mathrm{cfs}$ of water from the Bear River (nearly its entire flow) and store it in Bear Lake for downstream power generation. These early legal decrees imposed no operational restrictions on UP\&L's diversion, storage, or release of water in relation to Bear Lake. UP\&L's storage rights in Bear Lake and control over the lower half of Bear River created several potential sources of conflict.

Bear River Basin's geography and hydrology have created uncertainties and risks related to dividing the waters, avoiding over allocation, and meeting the needs of various upstream and downstream users in different states. The overriding challenge has been to reduce these uncertainties and risks by managing this highly variable resource in a predictable manner to meet the needs and interests of people who are linked to it in very different ways, and to have this management occur in separate but loosely connected forums for discussion, debate, and decision-making.

\section{2) Anticipating Drought}

In confronting aridity and hydrologic variability, people in the Bear River Basin experienced and came to anticipate climatic drought as inevitable and began building the institutional and adaptive capacity to deal with it. They prepared for human contingencies of future droughts by constructing a layered law of the river defined at the most general level by a series of significant 


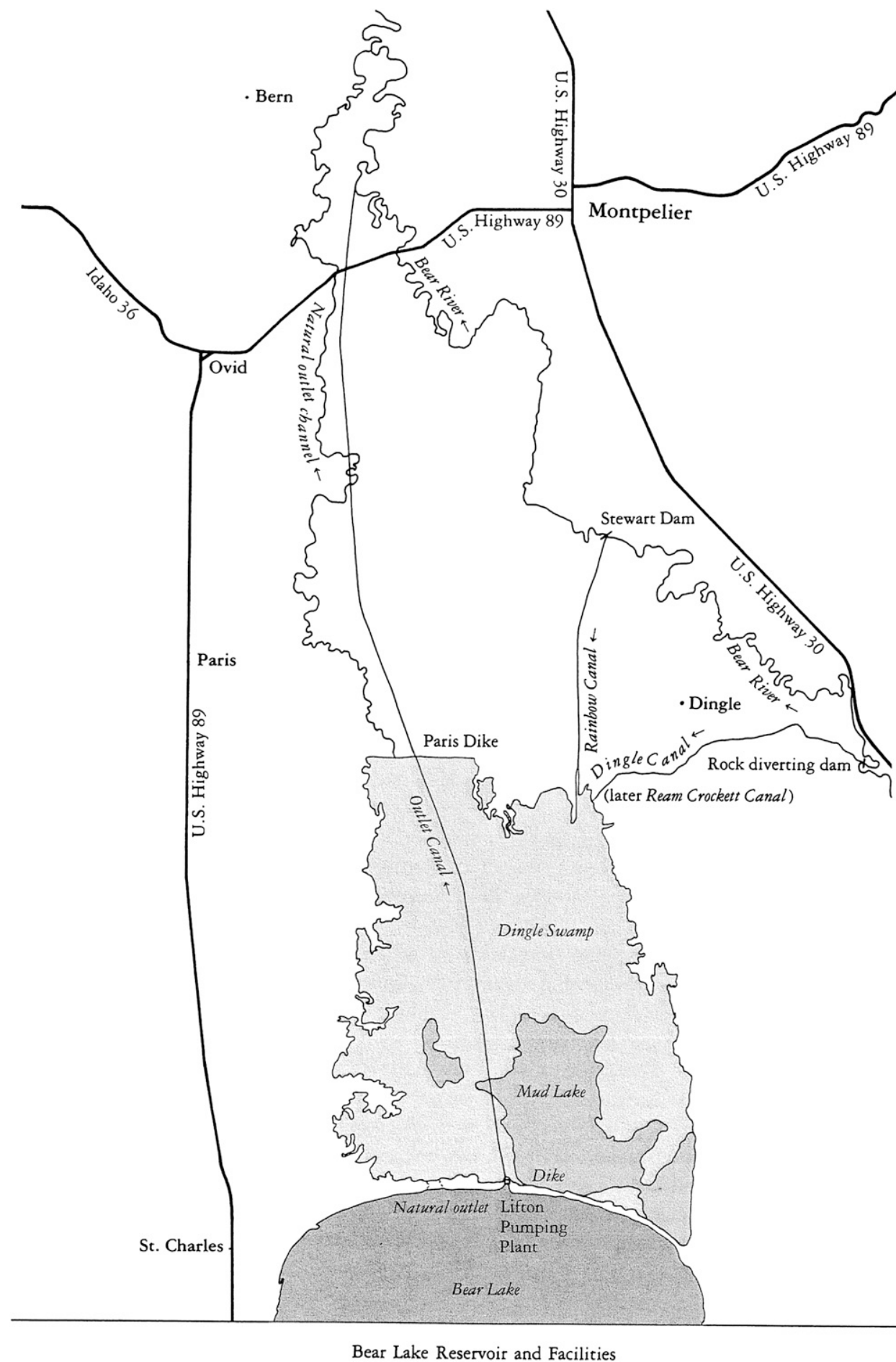

FIG. 3. Diversions into and from Bear Lake for water storage. [Source: McCarthy (1987), p. 64. Courtesy of Charles Redd Center for Western Studies, Brigham Young University.]

decisions (court decrees, an interstate compact, lawsuit settlements, voluntary settlement agreements). Many of these decisions resolved water scarcity issues that arose within the contexts of different time periods and were informed by different ways of knowing the river. Three features of the law of the Bear River are highlighted as illustrations of how, in anticipation of drought and having come to know the nature of human-hydrologic 


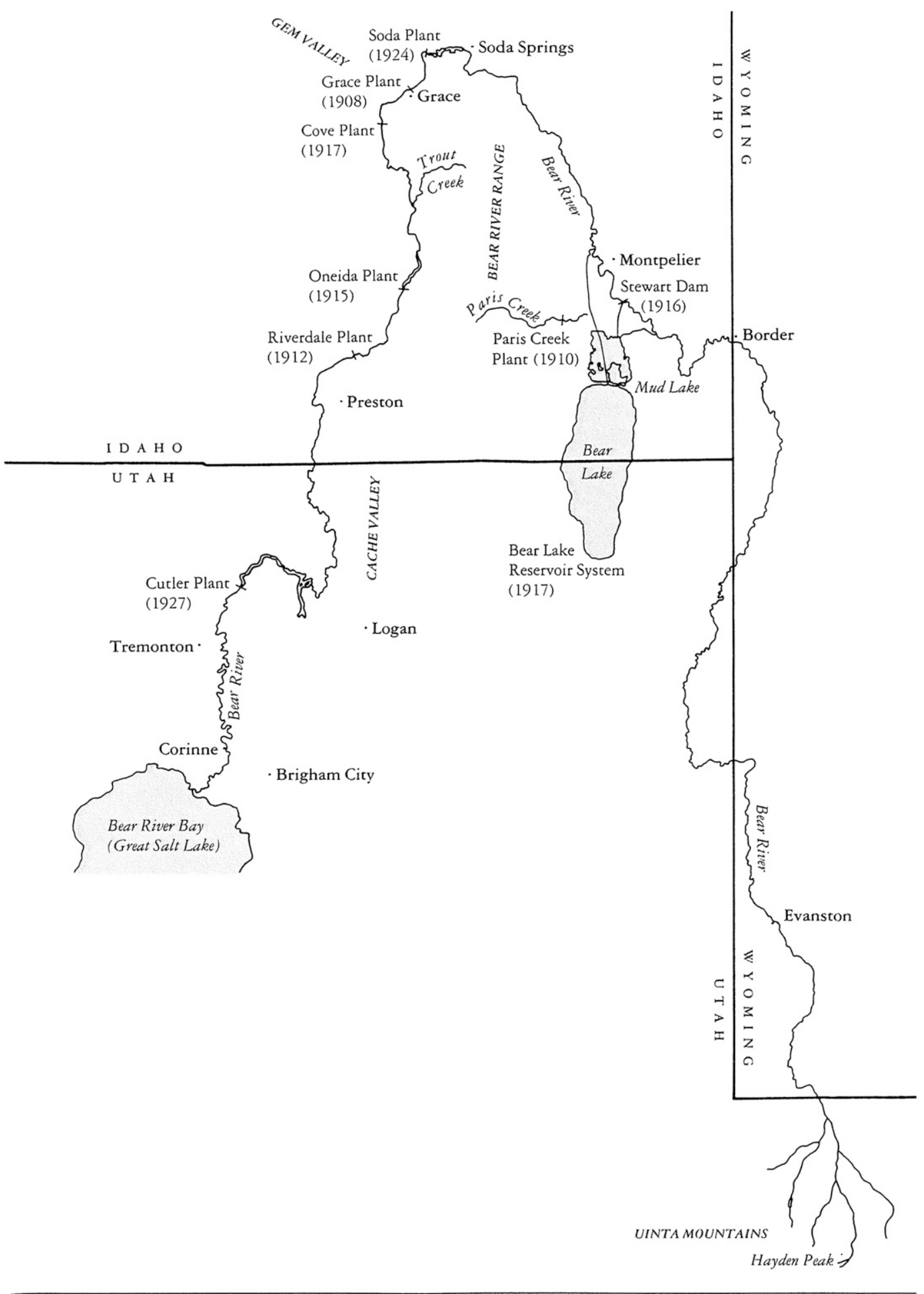

Bear River Watershed and Hydroelectric Plants

FIG. 4. Hydroelectric developments along the Bear River. [Source: McCarthy (1987), p. 7. Courtesy Charles Redd Center for Western Studies, Brigham Young University.] 
interdependence, people made choices to try to avoid future conflicts.

\section{(i) Prior appropriation.}

Water laws in Idaho, Utah, and Wyoming follow strict prior appropriation doctrines dating back to the United States territorial era of the late nineteenth century. These prior appropriation systems established rules for determining who gets water in times of scarcity, but they also declared water to be the property of the public and required that it be put to beneficial uses in reasonably efficient manners to avoid monopolization and waste. Prior appropriation modified frontier individualism with collective rationales for allocating scarce water. As the Bear River Basin grew, implementing the prior appropriation principle of "first come, first serve" was complicated by the transboundary nature of the Bear River and the fact that the oldest, largest, and most legally secure priority (claimed for irrigated agriculture) was located at the end of the river.

The early 1930s brought the driest consecutive five years in 65 years of human-recorded hydrologic history. The drought emphasized lack of storage upstream from Bear Lake. Although all water users in Bear River Basin struggled during the 1930s drought, users below Bear Lake were able to receive some relief through Bear Lake storage holdovers that were eventually depleted by 1935 . Users above Bear Lake had no storage water they could rely on during times of scarcity. The ability of irrigators above Bear Lake to develop their own storage was legally hindered by UP\&L's large diversion right for storage in Bear Lake. Yet even though UP\&L and downstream irrigators held decreed priorities, water users in the upper basin still held the geographic "hiority" (Jibson 1991, p. 7). The contradiction between "first in time" and "first in line" required cooperation to make prior appropriation water law work in that geographic context.

The severe drought of the 1930s made people acutely aware of the need to address interstate allocation of the river. The 1930s drought was a historical milestone that served as a significant boundary experience because people learned what a severe drought in the Bear River Basin meant in hydrologic and human terms and they subsequently focused their efforts on avoiding risks they now knew were possible if they did not cooperate. In response to that drought, the three states, with assistance from U.S. Geological Survey and Bureau of Reclamation personnel, negotiated for twelve years to develop the Bear River Compact, which was signed into federal law on 17 March 1958 (Jibson 1991).

\section{(ii) Bear River Compact.}

Wallace Jibson's history of negotiations over the Bear River Compact testifies to the tremendous normative and practical issues that were at stake. It includes considerable comment about the time and effort put into studying the river and meeting to discuss and deliberate. His history also documents the considerable "horsetrading," "compromise," "threatened walkouts," and often "heated discussion" that it took to "hammer out" differences (Jibson 1991, 9-19) as various rationalities were brought to bear on the issues. While states' negotiators were responsible for protecting water rights of users in their states, they also came to understand the risks of not cooperating in light of larger concerns over equitable allocation and comity between states and the need to coordinate hydrologic management across state lines, especially in times of drought. Several times agreements reached by negotiators were rejected by parties in their states, indicating that negotiators had arrived at a different way of knowing the river. The twelveyear process to reach agreement indicates that developing a common way of knowing Bear River was not easy.

The Compact specifies rights and obligations of the signatory states of Wyoming, Idaho, and Utah and was incorporated into their water laws. The framework established by the Bear River Compact did much to promote interstate respect and equitable apportionment of natural flow. Natural flow was divided among the three states based on a combination of duties of water for irrigated acreages and relative priorities (Jibson 1991, p. 13). The Bear River Compact set aside 36500 annual acre-feet for upstream storage, but the only way this could be done without impairing downstream irrigators in a nearly fully appropriated river basin was to reduce use of Bear Lake storage water solely for power production. This provision, in effect, required "simultaneous use" of water for irrigation and power production in times of shortage. Thus, the Compact set limits on Bear Lake withdrawals based on lake elevations. An irrigation reserve elevation of 5914.7 feet was established. When Bear Lake falls below this elevation, Bear Lake storage water cannot be released for the sole purpose of power generation. The Bear River Compact also reorganized the institutional geography of water management to better fit the physical geography of river hydrology in order to deal with administering priorities and water deliveries across state lines. The Bear River Basin was divided into three divisions: the Upper Division, the Central Division, and the Lower Division (Fig. 5). Each division only requires coordination between two of the three Basin states.

The Bear River Commission, established under provisions of the Bear River Compact, has served as a boundary organization since its formation. Its duties are to enforce Compact provisions and decide on more specific operational rules to make compliance possible. 


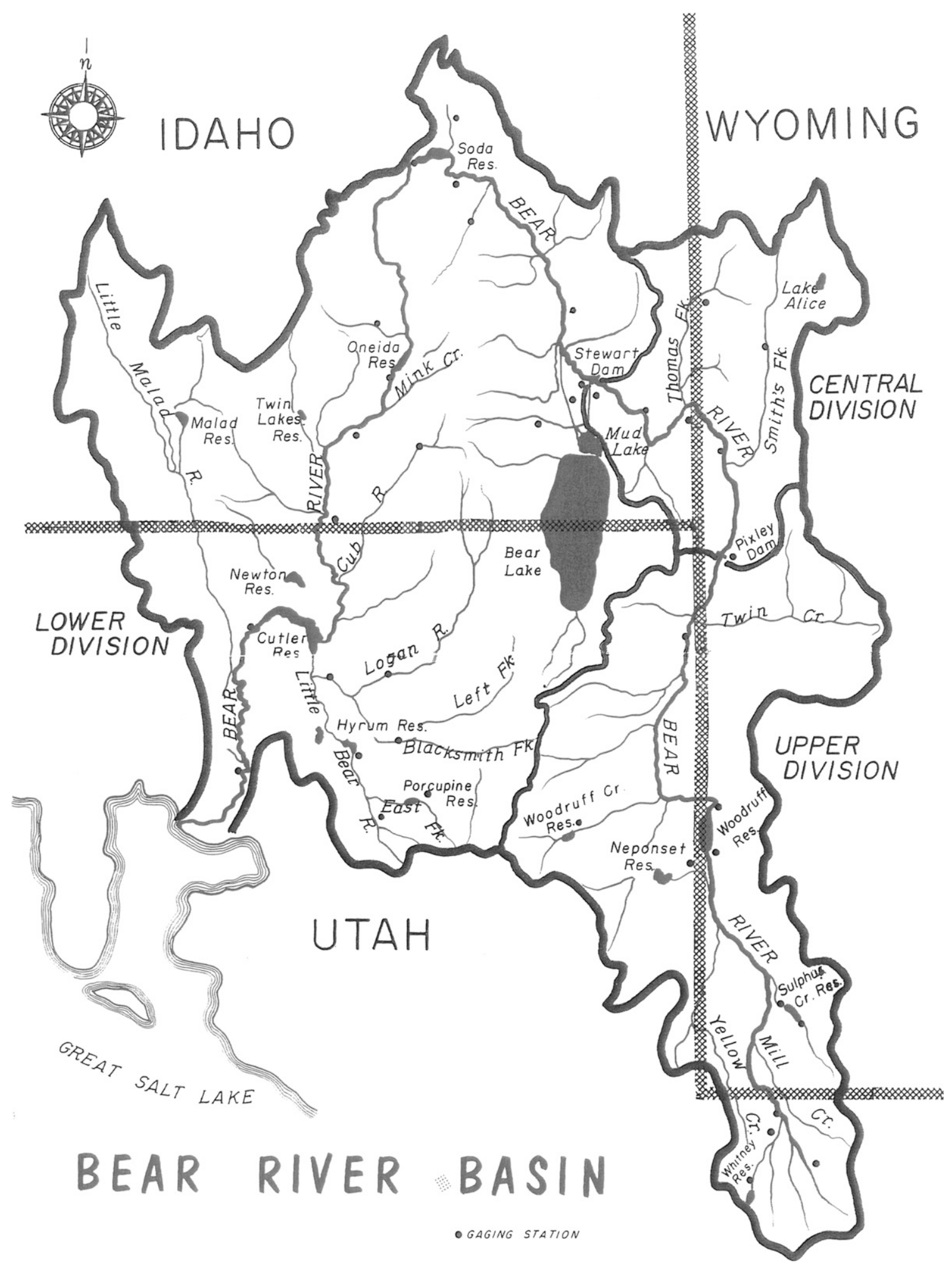

FIG. 5. Administration divisions for water management in the Bear River Basin. (Source: Jibson 1991.) 
The Commission leaves everyday operation of the river to the respective states unless there is a water emergency, which triggers interstate regulation. The Commission provides important interstate interactional networks, forums for debate, and administrative ordering for the Bear River Basin. Every twenty years, the Commission is directed to review the Compact to determine if any amendments are needed (Public Law 96-189; Bear River Commission 1997); thus, it can incorporate changes in ways of knowing as "new elements" are introduced in the Bear River Basin (Schneider and Ingram 2007, p. 3). Jack Barnett explained: "....collaboration comes because of the awareness of much worse consequences to not collaborating. Collaboration may occur best in situations where formal authority is well defined and articulated, but the cost is too high for any one party to win at the expense of another. Informal collaboration within formal structure; this facilitates collaboration."

\section{(iii) Bear Lake Settlement agreements.}

Bear Lake Watch, Inc., is an example of a new element that provided different perspectives and ways of knowing in the Bear River Basin. Their membership included famous retired football star Merlin Olsen and knowledgeable retired U.S. Forest Service employee James Kimbal. They were concerned about dropping lake elevations. Their way of knowing Bear Lake as an environmental and recreational lake implied a more stable but naturally fluctuating elevation and was very different from PacifiCorp's and the irrigators' ways of knowing it as a water storage reservoir that implied larger fluctuations with winter-spring storage and summer releases. Bear Lake interests filed suit against the U.S. Army Corps of Engineers over issuance of PacifiCorp's dredging permit during the early 1990s drought when the lake dropped too low for the outlet canal to function. The lawsuit acted as what Schneider and Ingram refer to as a "leverage point" that forced the three entities to work together to share and deliberate different ways of knowing (Schneider and Ingram 2007, p. 12).

PacifiCorp, irrigators, and Bear Lake Watch voluntarily negotiated the 1995 Bear Lake Settlement Agreement in an attempt to address their differences without litigation. The original and restated (2004) settlement agreements provide a way for the signatory parties to share water shortages during drought. As Bear Lake's elevation falls below the irrigation reserve of 5914.7 feet, irrigators agree to reduce diversion of storage allocations on a percentage basis until the lake drops to an estimated lake elevation of 5904 feet (Table 1), in effect slowing the lake's rate of decline. At 5904 feet, the irrigators and PacifiCorp agree to stop diverting water from Bear Lake and to set aside unused storage water to
TABLE 1. Bear Lake Settlement Agreement: Reduction in storage water allocations.

\begin{tabular}{ccc}
\hline \hline $\begin{array}{c}\text { Bear Lake } \\
\text { elevation } \\
\text { (feet) }\end{array}$ & $\begin{array}{c}\text { Storage } \\
\text { allocation } \\
\text { (acre-feet) }\end{array}$ & $\begin{array}{c}\text { Percentage of } \\
\text { full storage allocation }\end{array}$ \\
\hline 5914 & 225000 & $98 \%$ \\
5913 & 220000 & $96 \%$ \\
5912 & 215000 & $93 \%$ \\
5911 & 210000 & $91 \%$ \\
5910 & 205000 & $89 \%$ \\
5909 & 181000 & $79 \%$ \\
5908 & 168000 & $73 \%$ \\
5907 & 141000 & $61 \%$ \\
5906 & 104000 & $45 \%$ \\
5905 & 55000 & $24 \%$ \\
5904 & 0 & $0 \%$ \\
5903 & 0 & $0 \%$ \\
5902 & 0 & $0 \%$ \\
\hline
\end{tabular}

recover Bear Lake elevation rather than carrying it over to next year's storage allocations. Although the parties voluntarily agreed to share drought shortages, water rights stipulated in the Dietrich and Kimball decrees and contracts between irrigators and PacifiCorp remained in place and could still be enforced. Thus, the informal voluntary agreements work within the more formal legal structure without displacing it.

PacifiCorp has worked to manage hydropower operations around irrigation water deliveries and Bear Lake levels while avoiding difficult legal situations. Regional staff members have been very knowledgeable about and committed to the river and its people and have engaged in informational work and relational work throughout the Basin. Carly Burton, operational manager for Bear River for over 30 years, had unsurpassed knowledge of the river. Jody Williams, who helped forge the settlement agreements, explained, "PacifiCorp's bottom line is, it just doesn't want to incur difficult, legal situations and extended fights." PacifiCorp's staff, desire to avoid extended conflict, and current corporate management flexibility has enabled them to better understand other interests' ways of knowing.

\section{3) WAYS OF KNOWING IN THE BEAR RIVER BASIN}

People have utilized multiple ways of knowing to comprehend water in the Bear River Basin. For example, some people view water as a product and property (for irrigation and power production purposes); other people think about water as a natural element (regarding the ecological importance of Bear Lake and Bear River); and some people consider the cultural significance of water (the historical attachment to Bear Lake). The people of the Bear River Basin have shared and transformed their ways of knowing over time in order to 
adapt to unpredictable variability in both hydrologic and human systems. Informational work, relational work, boundary experiences (droughts), boundary organizations (Bear River Commission), and boundary objects (agreements, river models) have created more inclusive ways of knowing and a collective rationality that helped reduce conflict and further cooperation over water. Charles Holmgren noted that vulnerability to drought had forced them to appreciate other perspectives when he said, "it has been interesting how our ability to meet and talk has improved over the years. We've gotten to know people on the different sides of the question much better than we would have if we hadn't had the drought. We've gone from a point of not knowing people to disliking people to understanding people and seeing the different perspectives."

The ways of knowing framework helps us to interpret four other elements of the case study that suggest people in Bear River Basin see water more in relational and collective terms using multiple rationalities than in individualistic terms using self-interested rationality. First, various people in Bear River Basin have entered into voluntary agreements and honored commitments even when it was not always in their best interests to do so. Second, people's genuine surprise that the 2004 drought did not lead to more conflict suggested they were expecting self-interested behavior but that did not occur. Third, people have worked hard to avoid making a call on the river in the interest of comity and out of genuine empathy. Bob Fotheringham, at that time with the Utah Division of Water Rights, noted that the legal and organizational infrastructure makes an interstate call on the river possible but, if that had to occur, it would mean their efforts to manage the river had failed. Finally, Jack Barnett's observation that they had "physically stretched water" was less a reference to greater efficiency or altering a physical resource than an indication that a fundamental change in ways of knowing emerged during the 2004 drought whereby people did not see water allocation as a zero-sum game.

\section{Discussion}

The ways of knowing framework is distinct from most currently popular policy theories (e.g., institutional rational choice, game theory, interest group conflict) that are grounded in assumptions about self-interested human behavior and bounded rationality and that doubt people's ability to be guided by normative principles and to exercise self-governance. Schneider and Ingram (2007, p. 16) explain: "Our framework [ways of knowing]... assumes people are able to engage in empathetic reasoning and that humans desire to belong and to contribute to the public good just as much as they desire to compete and pursue only their own interests. We posit that multiple rationalities are available. In situations of collaboration where people come face to face with one another and engage in shared cooperative experiences, they come to recognize alternative ways of knowing and to respect these, as well as respect those who hold them. Cooperation is likely not just because it is a long-term selfinterest, but because people genuinely want to work together to produce better collective outcomes."

Water in the United States West is generally portrayed as a source of conflict rooted in self-interested competition to control scarce supplies, as illustrated in Mark Twain's famous quote, "Whiskey is for drinking; water is for fighting over." But water, especially in this regional "Mormon Country," has strong "genealogies," where people are connected through time in dedication to a religious cause greater than themselves and to building communities in a "Great Basin Kingdom" (Arrington 1958; Harvey 1989; Jibson 1991; McCarthy 1987; Powell 1878; Sadler and Roberts 1994; Stegner 1942, 1954). People in the Bear River Basin have brought various rationalities to bear upon managing water, including faith, practicality, efficiency, equity, obligation, respect, aesthetics, and economics. They have learned that cooperation in water's use is essential, water management is an issue best resolved locally, and adaptation to a highly variable and drought-prone hydrology is possible.

Bear River water veterans who participated in the 2004 Bear Lake Eco-Symposium wanted a recorded history of their 2004 drought response so the next generation would know what they did to make it through one of the worst droughts in over a century. What they did was important, but even more important was why and how they did it. They responded the way they did because they understood all too well risks to themselves and to others of not cooperating and ignoring the hard work generations of people had done to prepare for drought. Embedded in the law of the Bear River were results of past efforts to balance equitable apportionment with priority and efficiency concerns and to integrate various ways of knowing into a collective rationality for water management that emerged from years of experience with the river and deliberation with each other. The 2004 drought tested this law and, through respecting and honoring it, they were able to demonstrate how to cooperatively respond to drought. While their expressed desire to document the 2004 drought response related to concerns about losing experiential knowledge of hydrologic complexities that they understood all too well, the unspoken concern was that relationships they had built with each other would also be lost as they faced handing river management 
over to the next generation. The lesson Bear River veterans taught was that people have to keep working at different ways of knowing, continually combining informational work and relational work. The process of locally resolving water conflicts and forging cooperation over time in response to the drought-prone hydrology of the Bear River Basin are testaments to the challenges and power of deliberative democracy and adaptive learning that can come from it.

One might expect that after more than 150 years of water development under prior appropriation and an intricate law of the river, the Bear River Basin water situation would be "settled." The situation, however, continues to evolve. The Bear River Basin case study illustrates that conflicts over water are never really "resolved" and that cooperation could be characterized, in the words of Bob Fotheringham, as a "process of continually sizing up the next fight." Schneider and Ingram have noted that ways of knowing are "constantly being re-enacted in the human imagination and in human practice," and that ways of knowing have to adapt when new elements appear in a policy space (2007:3). Perceived in this light, ways of knowing people in relationship to water become critical bridges between the past and the future. When told that the purpose of our research was to write a contemporary history of the 2004 drought, Bob Fotheringham commented that what he wanted to know is how various players understood the Bear River situation, how they perceived the future, and what courses of action they intended to pursue as a consequence.

The historical development of human-hydrologic interdependencies in the Bear River Basin has acted as a fulcrum of conflict and cooperation over water. We have argued that people's ways of knowing and understanding these interdependencies is a determining factor in whether water-scarce situations pivot toward conflict or toward cooperation. Conflict rooted in self-interested behavior should not be the assumed model of human nature in dealing with scarce water resources. The ways of knowing framework helps us to understand that, instead, conflict or cooperation over water is a human choice that hinges on ways of knowing how people are connected through hydrology and history.

\section{Conclusions}

The Bear River Basin case study contributes to understanding human adaptation to drought, which is best characterized as a historically contextualized process where ways of knowing the particular interdependencies of human hydrology in a place are brought to bear on solving problems of water scarcity. These ways of knowing are not just predictive, but reflective too, and can be understood as "sense-making" (Schneider and Ingram 2007, p. 4). People in the Bear River Basin responded to the climatologic and hydrologic effects of the 2004 drought with knowledge, experience, and acumen developed during previous droughts and a law of the river built around what they had learned about water and about each other. Their interactions in attempting to manage water resources during the depth of a severe drought enabled them to develop new ways of knowing the Bear River Basin through which they avoided conflict and pursued cooperation.

People in the Bear River Basin have come to understand their linked vulnerability to variability in hydrologic and human systems. As predictions of climate change increase the uncertainty of future water supplies, new elements are entering the policy space of the Bear River Basin that increase the uncertainty of future water demands. These elements include environmental concerns (water quality and wetlands issues), growing urban communities within the Bear River Basin and along the Wasatch Front (the greater Ogden-Salt Lake CityProvo metropolitan corridor), and speculators active in developing markets in western water rights. The ways people in the Bear River Basin come to know and deal with these changes will be important in determining their water future and their ability to adapt to future droughts.

Acknowledgments. The authors wish to acknowledge and thank the many people who participated in this research by providing information and insights, being interviewed, and sharing conversations. They would also like to thank the journal's insightful reviewers and helpful editors; as well as Helen Ingram for her generous review and suggestions on an earlier version of this manuscript. This research was funded as part of the Drought Management Project at Utah State University by the USDA CSREES.

\section{REFERENCES}

Adger, W. N., 2006: Vulnerability. Global Environ. Change, 16, 268-281.

Allen, T. F. H., J. A. Tainter, and T. W. Hoekstra, 2003: SupplySide Sustainability. Columbia University Press, 459 pp.

Arnold, T. C., 2008: The San Luis Valley and the moral economy of water. Water, Place and Equity, J. M. Whiteley, H. Ingram, and R. W. Perry, Eds., MIT Press, 37-68.

Arrington, L. J., 1958: Great Basin Kingdom: An Economic History of the Latter-Day Saints, 1830-1900. Harvard University Press, $534 \mathrm{pp}$.

Barlow, M., 2008: Blue Covenant: The Global Water Crisis and the Coming Battle for the Right to Water. The New Press, 208 pp.

Beach, H. L., J. Hamner, J. J. Hewitt, E. Kaufman, A. Kurki, J. A. Oppenheimer, and A. T. Wolf, 2000: Transboundary 
Freshwater Dispute Resolution: Theory, Practice, and Annotated References. United Nations University Press, 320 pp.

Bear River Commission, 1997: Findings concerning the need for compact revision: A report made as a part of the twenty-year review effort provided for by Article XIV of the Amended Bear River Compact. Bear River Commission, 13 pp.

Berkes, F., and C. Folke, 1998: Linking Social and Ecological Systems: Management Practices and Social Resilience. Cambridge University Press, $476 \mathrm{pp}$.

Bernhardt, E., and Coauthors, 2006: Perspective: The challenge of ecologically sustainable water management. Water Policy, 8, 475-479.

Blatter, J., and H. Ingram, Eds., 2001: Reflections on Water: New Approaches to Transboundary Conflicts and Cooperation. MIT Press, 356 pp.

- - -, and P. Doughman, 2001: Emerging approaches to comprehend changing global contexts. Reflections on Water: New Approaches to Transboundary Conflicts and Cooperation, J. Blatter and H. Ingram, Eds., MIT Press, 3-29.

Burton, I., S. Huq, B. Lim, O. Pilifosova, and E. L. Schipper, 2002: From impacts assessments to adaptation priorities: The shaping of adaptation policy. Climate Policy, 2, 145-159.

Clark, E. H., II, G. Bingham, and S. G. Orenstein, 1991: Resolving water disputes: Obstacles and opportunities. Resolve, 23, 1-7.

Clark, W. C., and N. M. Dickson, 2003: Sustainability science: The emerging research program. Proc. Natl. Acad. Sci. USA, 100, 8059-8061.

Dean, W. E., R. M. Forester, J. Bright, and R. Y. Anderson, 2007: Influence of the diversion of Bear River into Bear Lake (Utah and Idaho) on the environment of deposition of carbonate minerals. Limnol. Oceanogr., 52, 1094-1111.

Denton, C., 2007: Bear River: Last Chance to Change Course. Utah State University Press, $250 \mathrm{pp}$

de Villiers, M., 2000: Water: The Fate of Our Most Precious Resource. Houghton Mifflin, $368 \mathrm{pp}$.

Draper, S., Ed., 2006: Sharing Water in Times of Scarcity. American Society of Civil Engineers, $156 \mathrm{pp}$.

Durley, J. L., and R. C. de Loe, 2005: Empowering communities to carry out drought contingency planning. Water Policy, 7, 551-567.

Epstein, P. R., and J. J. McCarthy, 2004: Assessing climate stability. Bull. Amer. Meteor. Soc., 85, 1863-1870.

Feldman, D. L., 1991: Water Resources Management: In Search of an Environmental Ethic. Johns Hopkins University Press, $264 \mathrm{pp}$.

Feldman, M. S., and A. M. Khademian, 2007: The role of public manager in inclusion: Creating communities of participation. Governance, 20, 305-324.

,,-- H. Ingram, and A. S. Schneider, 2006: Ways of knowing and inclusive management practices. Public Adm. Rev., 66, 89-99.

Fischhendler, I., 2004: Legal and institutional adaptation to climate uncertainty: A study of international rivers. Water Policy, 6, 281-302.

Fraser, E. D. G., 2007: Traveling in antique lands: Using past famines to develop an adaptability/resilience framework to identify food systems vulnerable to climate change. Climatic Change, 83, 495-514.

Gleick, P., G. Wolff, E. L. Chalecki, and R. Reyes, 2002: The new economy of water: The Risks and benefits of globalization and privatization of fresh water. Pacific Institute for Studies in Development, Environment, and Security, $61 \mathrm{pp}$.

Grover, V. I., Ed., 2007: Water: A Source of Conflict or Cooperation? Science Publishers, 360 pp.
Guston, D. H., 2001: Boundary organizations in environmental policy and science. Sci. Technol. Human Values, 26, 399408.

Harvey, J. S., 1989: A historical overview of the evolutions of institutions dealing with water resource use, and water resource development in Utah-1847 through 1947. M.S. thesis, Dept. of History, Utah State University, $106 \mathrm{pp}$.

Hayes, M. J., M. Svoboda, D. Le Comte, K. T. Redmond, and P. Pasteris, 2005: Drought monitoring: New tools for the 21st century. Drought and Water Crises: Science, Technology, and Management Issues, D. A. Wilhite, Ed., Taylor and Francis, 53-69.

Hulme, M., 2007: Geographical work at the boundaries of climate change. Trans. Inst. Br. Geogr., 33, 5-11.

Ingram, H., and J. Endter-Wada, 2009: Frames and ways of knowing: Key considerations for policy responses to climate risk and vulnerability. Proc. Seventh Int. Science Conf. on the Human Dimensions of Global Environmental Change, Bonn, Germany, International Human Dimensions Programme. [Available online at http://www.openmeeting2009.org/pdf_files/Pdf\%20papers/ Microsoft\%20Word\%20-\%20Ingram_Endter_paper1_final-1. pdf.]

Janssen, M. A., M. L. Schoon, W. Ke, and K. Börner, 2006: Scholarly networks on resilience, vulnerability, and adaptation within the human dimensions of global environmental change. Global Environ. Change, 16, 240-252.

Jibson, W. N., 1991: History of the Bear River Compact. Bear River Commission, 35 pp. [Available online at http://waterrights. utah.gov/techinfo/bearrivc/history.html.]

Just, R. E., and S. Netanyahu, Eds., 1998: Conflict and Cooperation on Trans-Boundary Water Resources. Springer, $460 \mathrm{pp}$.

Lejano, R. P., and H. Ingram, 2008: Collaborative networks and new ways of knowing. Environ. Sci. Policy, in press, doi:10.1016/ j.envsci.2008.09.005.

McCarthy, M. R., 1987: The Last Chance Canal Company. Charles Redd Center for Western Studies, Brigham Young University, $131 \mathrm{pp}$.

Nicholls, N., M. J. Coughlan, and K. Monnik, 2005: The challenge of climate prediction in mitigating drought impacts. Drought and Water Crises: Science, Technology, and Management Issues, D. A. Wilhite, Ed., Taylor and Francis, 33-51.

O'Brien, K., S. Eriksen, L. P. Nygaard, and A. Schjolden, 2007: Why different interpretations of vulnerability matter in climate change discourses. Climate Policy, 7, 73-88.

Ostrom, E., 2008: Frameworks and theories of environmental change. Global Environ. Change, 18, 249-252.

Polsky, C., and D. W. Cash, 2005: Drought, climate change, and vulnerability: The role of science and technology in a multiscale, multi-stressor world. Drought and Water Crises: Science, Technology, and Management Issues, D. A. Wilhite, Ed., Taylor and Francis, 215-245.

Postel, S., and B. Richter, 2003: Rivers for Life: Managing Water for People and Nature. Island Press, $220 \mathrm{pp}$.

Powell, J. W., 1878: Report on the lands of the arid region of the United States, with a more detailed account of the lands of Utah. Government Printing Office, 195 pp.

Rolfe, J. T., 2008: Risks, vulnerability and participation: A layered management approach. Economics and Management of Climate Change: Risks, Mitigation, and Adaptation, B. Hansjurgens and R. Antes, Eds., Springer, 79-96.

Sadler, R. W., and R. C. Roberts, 1994: The Weber River Basin: Grass Roots Democracy and Water Development. Utah State University Press, 283 pp. 
Schneider, A. L., and H. Ingram, 1997: Policy Design for Democracy. University Press of Kansas, 241 pp.

, and - Eds., 2005: Deserving and Entitled: Social Constructions and Public Policy. State University of New York Press, $371 \mathrm{pp}$.

— , and — 2007: Ways of knowing: Implications for public policy. Proc. 2007 Annual Meeting of the American Political Science Association, Chicago, IL, APSA. [Available online at http://www.cspo.org/documents/ways_of_knowing.pdf.]

Shiva, V., 2002: Water Wars: Privatization, Pollution, and Profit. South End Press, 156 pp.

Simelton, E., E. D. G. Fraser, M. Termansen, P. M. Forster, and A. J. Dougill, 2009: Typologies of crop-drought vulnerability: An empirical analysis of the socio-economic factors that influence the sensitivity and resilience to drought of three major food crops in China (1961-2001). Environ. Sci. Policy, 12, 438452, doi:10.1016/j.envsci.2008.11.005.

Smakhtin, V. U., and E. L. F. Schipper, 2008: Droughts: The impact of semantics and perceptions. Water Policy, 10, 131-143.

Smit, B., and J. Wandel, 2006: Adaptation, adaptive capacity, and vulnerability. Global Environ. Change, 16, 282-292.

Star, S. L., and J. Griesemer, 1989: Institutional ecology, translations and boundary objects: Amateurs and professionals in Berkeley's museum of vertebrate zoology. Soc. Stud. Sci., 19, 387-420.

Stegner, W., 1942: Mormon Country. Duell, Sloan, and Pearce, $362 \mathrm{pp}$

— 1954: Beyond the Hundredth Meridian: John Wesley Powell and the Second Opening of the West. Houghton Mifflin, 438 pp.

Steinemann, A. C., and L. F. N. Cavalcanti, 2006: Developing multiple indicators and triggers for drought plans. J. Water Resour. Plann. Manage., 132, 164-174.
Tainter, J. A., 1988: The Collapse of Complex Societies. Cambridge University Press, $250 \mathrm{pp}$.

Watts, M., and H. Bohle, 1993: The space of vulnerability: The causal structure of hunger and famine. Prog. Hum. Geogr., 17, 43-67.

Weber, E., and A. Khademian, 2008: Wicked problems, knowledge challenges, and collaborative capacity builders in network settings. Public Adm. Rev., 68, 334-349.

Whiteley, J. M., H. Ingram, and R. W. Perry, Eds., 2008: Water, Place, and Equity. MIT Press, 318 pp.

Wilhite, D. A., Ed., 2005: Drought and Water Crises: Science, Technology, and Management Issues. Taylor and Francis, $406 \mathrm{pp}$.

— , and M. Buchanan-Smith, 2005: Drought as hazard: Understanding the natural and social context. Drought and Water Crises: Science, Technology, and Management Issues, D. A. Wilhite, Ed., Taylor and Francis, 3-29.

_ M. J. Hayes, and C. L. Knutson, 2005: Drought preparedness planning: Building institutional capacity. Drought and Water Crises: Science, Technology, and Management Issues, D. A. Wilhite, Ed., Taylor and Francis, 93-135.

_ M. D. Svoboda, and M. J. Hayes, 2007: Understanding the complex impacts of drought: A key to enhancing drought mitigation and preparedness. Water Resour. Manage., 21, 763 774.

Wolf, A. T., 1998: Conflict and cooperation along international waterways. Water Policy, 1, 251-265.

—-, Ed., 2002: Conflict Prevention and Resolution in Water Systems. Edward Elgar, 823 pp.

, S. B. Yoffe, and M. Giordano, 2003: International waters: Identifying basins at risk. Water Policy, 5, 29-60. 